\title{
15. OXYGEN 18 AND CARBON 13 ISOTOPES FROM BULK CARBONATE SAMPLES, LEG 47B
}

\author{
René R. Létolle, Laboratoire de Géologie Dynamique, Université Pierre et Marie Curie, Paris
}

Eighty samples of carbonate from Leg 47B were analyzed for $\mathrm{O}^{18}$ and $\mathrm{C}^{13}$. Data show the isotopic profiles from Cretaceous upward are similar to those obtained in the Pacific and southern Atlantic oceans, especially for the EoceneOligocene transition. Isotope data, however, indicate differences in the paleoceanolographic setting.

Isotope ratios were measured on bulk carbonate samples from Hole 398D (see values on Table 1), for comparative purposes with other DSDP legs (i.e., Legs 16 and 44) and for testing the data obtained on such materials for their value as paleoecological indicators.

Foraminifers are the most common material used for isotope studies, and the comparison between planktonic and benthic species leads to useful information (Shackleton, 1967). However, the coccoliths which form the bulk of carbonate material in most samples also have been tested (Margolis et al., 1975) and have shown isotope ratios similar to those for planktonic foraminifers. In some cases, data obtained on bulk material also were presented (Douglas and Savin, 1973), which fit well with foraminiferal isotopic values.

Eighty bulk carbonate samples from Leg 47B were analyzed, using classical techniques; reproducibility is about 0.1 per mil for $\mathrm{O}^{18}$ and somewhat better for $\mathrm{C}^{13}$. When extraction of foraminifers was possible, their analysis was performed; those data will be analyzed by Vergnaud-Grazzini (this volume) toprovide a comparison with bulk carbonate data.

The isotope values for bulk carbonates are the result of several factors:

1) The composition of initial fossil material, either planktonic or benthic. The latter never constitutes an important fraction of the material. In all the material studied from Leg 47B, we observed that most of the figured calcite were coccoliths. For fresh material, it may be concluded that isotope analyses reflect the composition of the coccolith component.

2) Mixing of detrital material. This is easily verified by paleontologists and occurred in Cretaceous beds of Leg 47B (see Sigal, this volume). Biasing of the isotope record also may be of consequence when analysis is performed on selected fossils.

3) Dissolution and recrystallization. Dissolution of fossil tests occurs during their fall towards the sea floor and prior to their burial. (This effect on the preservation of the isotopic record is presently under investigation in various laboratories.) Subsequently, authigenic calcite forms and its importance grows with the depth of the burial. It is generally different in its characteristics from biogenic calcite, especially for isotope contents, because the temperature and isotope composition of interstitial waters may be completely different from those where the carbonate originally formed.
Before the isotope analyses were made, samples of the oldest sediments were studied petrographically and appeared to be highly recrystallized. Higher in the stratigraphic series (Danian and Eocene chalks), the recrystallized carbonate component appeared to be less important, and it is only in the uppermost samples (Core 2) that recrystallized material is absent. The sequence of recrystallization seems to be the same as that observed in other sediment series, for instance in Legs 2 and 17 (Lancelot et al., 1972; Schlanger et al., 1973).

Although the original $\mathrm{O}^{18}$ record is sensitive to such diagenesis, the same is not true for $\mathrm{C}^{13}$ which retains its original value more easily.

In analyzing the data, several sets of points appear on the scatter diagram $\mathrm{C}^{13} / \mathrm{O}^{18}$ (Figure 1), but the most discernible gap appears during the Eocene; the transition being approximately in Core 19 where a shift occurs in $\mathrm{O}^{18}$ values (Figure 2). Such an event already has been observed in most isotope studies of foraminifers at the Eocene-Oligocene transition, with some possible variations in its precise stratigraphic position (Savin et al., 1975; Douglas and Savin, 1971; Kennett and Shackleton, 1976) in both the Pacific and the southern Atlantic oceans. In every case, the shift is about $1 \% 00$ delta unit. One cannot ascertain if the transition here is later or earlier than at other locations, but it may be compared to the one observed by Shackleton and Kennett (1975a, b) at subantarctic sites (Campbell Plateau).

It appears highly improbable that such a synchronism could be due to diagenesis for such widely spaced locations. More likely, its origin is a significant, geodynamic event. This could be either the intrusion of antarctic waters (Shackleton and Kennett, 1975a) to these northern latitudes, or the easier communication of arctic waters with the Atlantic Ocean. Regional tectonic events, such as the rotation of Spain, also seem to be synchronous with the isotopic change in carbonates.

Other mineralogical indicators (Chamley et al., this volume) indicate a drastic change in water circulation as well as in continental climatic conditions at the same time.

The following remarks can be made relative to the different episodes of carbonate sedimentation:

1) Pre-Cenomanian carbonates: Sedimentological and micropaleontological studies (this volume) show the multiple origins of carbonate and that recrystallization is important. However, oxygen isotope values differ from those observed in contemporary beds from Legs 11 and 44 in the western Atlantic (Brenneke, 1977; Létolle et al., 1978), where much lower $\mathrm{O}^{18}$ values are interpreted as being due to recrystallization in a high geothermal gradient setting and/or hydrothermal influences not evident at Hole 398D.

2) Campanian to late Eocene: Carbonate material is much less recrystallized in this interval. From Cores 48 to 22 a slow 
TABLE 1

Stable Isotope Contents of Bulk Carbonate in Hole 398D

\begin{tabular}{|c|c|c|c|}
\hline Age & $\begin{array}{c}\text { Sample } \\
\text { (Interval in } \mathrm{cm} \text { ) }\end{array}$ & $\begin{array}{l}513 \mathrm{C} \\
(0 / 00)\end{array}$ & $\begin{array}{l}518 \mathrm{O} \\
(0 / 00)\end{array}$ \\
\hline Early Pliocene & $\begin{array}{ll}2-2, & 41-45 \\
2-2, & 65-67 \\
2-3, & 10-14\end{array}$ & $\begin{array}{l}+0.56 \\
-0.10 \\
+1.11\end{array}$ & $\begin{array}{l}+1.32 \\
+0.73 \\
+1.20\end{array}$ \\
\hline Miocene & $\begin{array}{cc}3-1, & 96-98 \\
3-2, & 70-71 \\
3-3, & 44-45 \\
3-3, & 65-67 \\
3-4, & 68-70 \\
3-5, & 62-64 \\
3-6, & 72-74 \\
4-2, & 60-62 \\
4-3,107-111 \\
5-5,107-111 \\
5-2, \quad 40-42 \\
5-2, \quad 60-62 \\
5-4, \quad 44-46 \\
5-5,130-134 \\
6-3, \quad 44-42 \\
6-3, \quad 60-62 \\
6-4, \quad 31-35 \\
7-2, \quad 58-60 \\
7-5, \quad 80-82 \\
8-2, \quad 50-51 \\
8-5, \quad 77-79 \\
9-3, \quad 99-101 \\
9-5, \quad 79-81 \\
12-1,110-111 \\
12-2,100-101 \\
12-3, \quad 44-47 \\
12-5, \quad 45-46 \\
12-5,100-101\end{array}$ & $\begin{array}{l}+1.08 \\
+0.80 \\
+1.14 \\
+1.29 \\
+1.02 \\
+0.25 \\
+0.37 \\
+0.96 \\
+1.80 \\
+1.87 \\
+1.53 \\
+1.63 \\
+1.60 \\
+2.04 \\
+2.40 \\
+2.60 \\
+2.65 \\
+1.54 \\
+2.01 \\
+2.56 \\
+2.29 \\
+1.73 \\
+1.50 \\
+1.20 \\
+1.72 \\
+1.58 \\
+1.69 \\
+1.97\end{array}$ & $\begin{array}{l}+1.31 \\
+0.84 \\
+0.70 \\
+1.26 \\
+0.84 \\
+0.81 \\
+0.07 \\
+0.94 \\
+1.30 \\
+1.04 \\
+1.35 \\
+1.08 \\
+1.44 \\
+1.67 \\
+1.32 \\
+1.52 \\
+1.68 \\
+1.03 \\
+1.01 \\
+1.53 \\
+1.34 \\
+1.42 \\
+1.07 \\
+1.14 \\
+1.63 \\
+0.60 \\
+1.55 \\
+1.63\end{array}$ \\
\hline Late Oligocene & $\begin{array}{ll}13-2, & 60-64 \\
13-3, & 62-64 \\
13-5, & 66-68 \\
14-1, & 35-37 \\
15-2, & 45-46 \\
15-3, & 67-69 \\
15-5, & 62-64\end{array}$ & $\begin{array}{l}+1.35 \\
+1.54 \\
+1.12 \\
+1.53 \\
+1.37 \\
+0.99 \\
+0.90\end{array}$ & $\begin{array}{l}+1.17 \\
+1.11 \\
+1.56 \\
+1.54 \\
+1.30 \\
+0.79 \\
+0.85\end{array}$ \\
\hline Mid-Oligocene & $17-1, \quad 32-34$ & +1.51 & +0.97 \\
\hline Late Eocene & $\begin{array}{l}19-3, \quad 50-51 \\
20-1, \quad 80-82 \\
20-3, \quad 67-70 \\
20-3,118-120 \\
21-4, \quad 49-51 \\
22-3, \quad 23-25\end{array}$ & $\begin{array}{l}+1.66 \\
+1.90 \\
+1.74 \\
+2.15 \\
+1.90 \\
+1.66\end{array}$ & $\begin{array}{l}+1.19 \\
-0.75 \\
+0.55 \\
-0.94 \\
-0.48 \\
-0.03\end{array}$ \\
\hline Middle Eocene & $\begin{array}{l}23-2, \quad 41-45 \\
25-1,102-104 \\
26-2, \quad 39-41 \\
27-4, \quad 89-91 \\
28-2, \quad 54-56 \\
30-4,132-134\end{array}$ & $\begin{array}{l}+1.72 \\
+1.61 \\
+1.57 \\
+1.55 \\
+1.75 \\
+1.74\end{array}$ & $\begin{array}{l}-0.62 \\
-0.33 \\
-0.02 \\
-0.27 \\
-0.80 \\
-1.12\end{array}$ \\
\hline Early Eocene & $\begin{array}{l}32-1, \quad 95-97 \\
33-2,141-142 \\
34-1, \quad 53-55 \\
35-2, \quad 77-79\end{array}$ & $\begin{array}{l}+1.04 \\
+0.71 \\
+1.16 \\
+1.44\end{array}$ & $\begin{array}{l}-1.60 \\
-0.93 \\
-0.44 \\
-0.75\end{array}$ \\
\hline Middle Danian & $\begin{array}{l}36-2,100-102 \\
37-3, \quad 69-71 \\
38-2, \quad 56-58\end{array}$ & $\begin{array}{l}+2.55 \\
+2.12 \\
+2.15\end{array}$ & $\begin{array}{l}-0.85 \\
-1.40 \\
-0.45\end{array}$ \\
\hline Early Danian & $40-1, \quad 9-11$ & +1.63 & -0.11 \\
\hline $\begin{array}{l}\text { "Transition to } \\
\text { Cretaceous" }\end{array}$ & $\begin{array}{lr}41-2, & 8-10 \\
41-2, & 31-33 \\
41-2, & 38-40 \\
41-2, & 45-47 \\
41-2, & 65-68 \\
41-2, & 131-133\end{array}$ & $\begin{array}{l}+1.38 \\
+0.90 \\
+1.61 \\
+2.19 \\
+2.24 \\
+2.38\end{array}$ & $\begin{array}{l}-0.25 \\
-0.26 \\
-1.08 \\
-0.27 \\
-0.37 \\
+0.12\end{array}$ \\
\hline Maestrichtian & $\begin{array}{ll}43-2, & 16-18 \\
45-1, & 18-20\end{array}$ & $\begin{array}{l}+2.53 \\
+2.02\end{array}$ & $\begin{array}{l}-0.43 \\
-0.59\end{array}$ \\
\hline Campanian & $\begin{array}{ll}46-2, & 28-30 \\
48-1, & 13-15 \\
49-1, & 36-38\end{array}$ & $\begin{array}{l}+1.69 \\
+1.83 \\
+1.40\end{array}$ & $\begin{array}{l}-0.43 \\
-0.74 \\
-0.67\end{array}$ \\
\hline Cenomanian & $56-5, \quad 88-90$ & +1.61 & -2.62 \\
\hline Late Aptian & $\begin{array}{ll}103-3, & 29-31 \\
106-1, & 36-38\end{array}$ & $\begin{array}{l}+1.66 \\
-0.38\end{array}$ & $\begin{array}{l}-1.38 \\
-1.11\end{array}$ \\
\hline Barremian & $133-2,51-53$ & +1.31 & -1.77 \\
\hline Hauterivian & $\begin{array}{ll}134-2, & 78-80 \\
135-2, & 27-29 \\
137-2, & 24-26 \\
138-1, & 38-40\end{array}$ & $\begin{array}{l}+1.50 \\
+1.09 \\
+1.10 \\
+1.08\end{array}$ & $\begin{array}{l}-1.47 \\
-1.74 \\
-1.46 \\
-1.57\end{array}$ \\
\hline
\end{tabular}

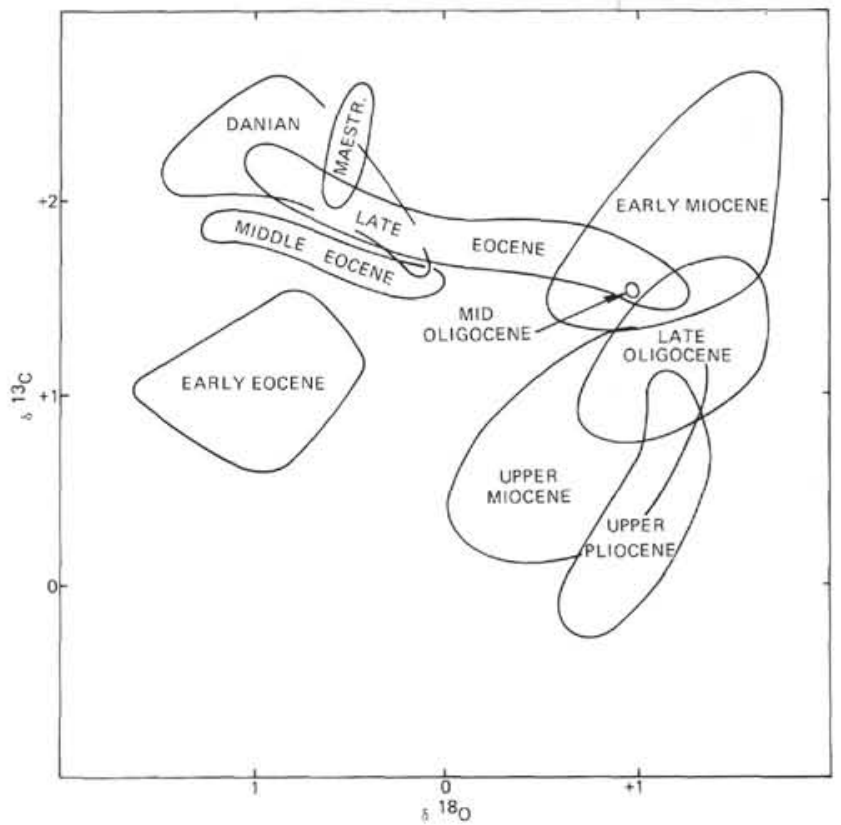

Figure 1. Carbon 13-oxygen diagram for bulk carbonates from Hole $398 D$.

trend towards higher $\mathrm{O}^{18}$ values exists. This is tentatively interpreted as a slow cooling of about $3^{\circ} \mathrm{C}$ in water temperatures. Other important fluctuations appear in the profile on Figure 2 which may correspond to climatic episodes that the widely spaced sampling interval is unable to define.

3) Post-Eocene: Fluctuations of about \pm 0.3 per mil occur around the mean $\delta^{18} \mathrm{O}$ value which itself does not show any characteristic trend, as observed by others in the Pacific or southern Atlantic. The values for the Miocene are about $1 \%$ delta unit higher here than in other areas. Long-range comparisons are hazardous due to the different paleogeographical settings. It is possible that at Hole 398D, after the late Eocene event, arctic waters already had a strong influence on other deep water sources which, for topographical reasons, was not true in the Pacific and southern Atlantic.

Carbon 13 is rarely interpreted in carbonate isotope studies. It is much less sensitive to recrystallization than $\mathrm{O}^{18}$, due to a much smaller temperature dependence in fractionation factors and to a much smaller ambient reservoir with which to exchange after burial (this is not the case for oxygen, an abundant constituent of interstitial waters). Carbon isotopes tentatively may be interpreted as a "production paleodepth" indicator. Duplessy (1972) has shown that bicarbonate is much richer in $\mathrm{C}^{13}$ in shallow waters than in deeper ones, and that this is reflected in biogenic calcite. Higher $\mathrm{C}^{13}$ values in fossil carbonates, therefore, can correspond to a greater contribution of the surface waters in the carbonate production.

High $\mathrm{C}^{13}$ values exist between Maestrichtian and early Eocene, indicating shallow water production. There is, however, an important break at the Cretaceous-Tertiary transition, which is not reflected in $\mathrm{O}^{18}$ values. Eocene $\mathrm{C}^{13}$ values are distinctly lower (Figure 1), and this may be a true indicator of the advent of deeper (Antarctic?) waters at some time. It is seen from Figure 1 that differences exist between the early and late Eocene. Large fluctuations exist from the 


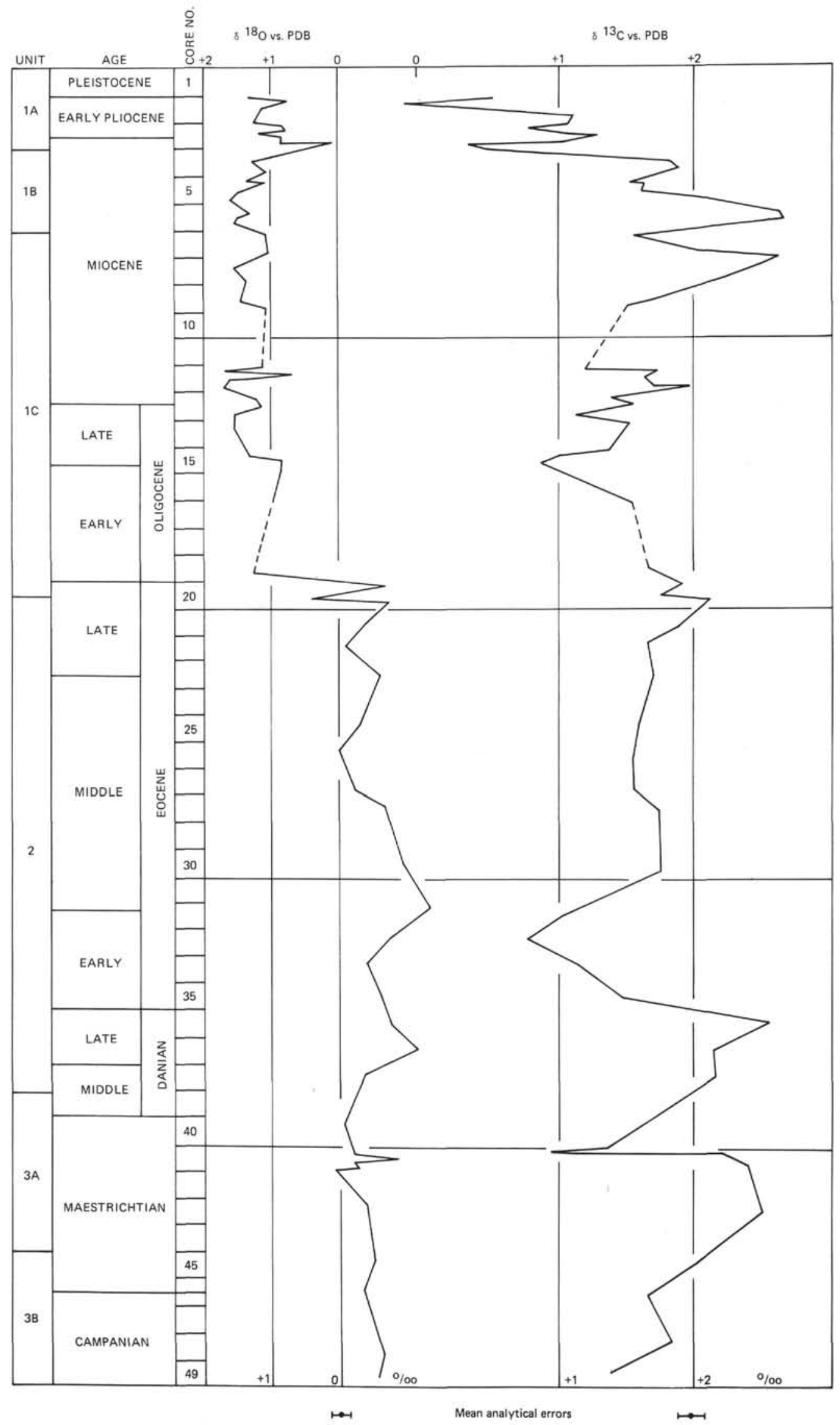

Figure 2. Isotope profiles for the upper part of Hole 398D. 
Oligocene upwards, which are difficult to relate to any significant events. Such fluctuations may be due to the proximity of epicontinental seas of short duration along the European margin. The distinct lowering of $\mathrm{C}^{13}$ values after Core 6 indisputably reflects the growing influence of deep arctic waters.

\section{ACKNOWLEDGMENTS}

I thank Drs. C. Vergnaud-Grazzini, Y. Lancelot, C. Müller, and O. Weser for helpful critical comments. Miss A. Filly assisted in the analytical work. CNEXO and CNRS provided material support to this study.

\section{REFERENCES}

Brenneke, J. C., 1977. A comparison of the stable oxygen and carbon isotope composition of Early Cretaceous and Late Jurassic carbonates from Sites 105 and 367. In Lancelot, Y., Siebold, E., et al., Initial Reports of the Deep Sea Drilling Project, v. 41: Washington (U.S. Government Printing Office), p. 937. 956.

Douglas, R. G. and Savin, S. M., 1971. Isotopic analyses of planktonic foraminifera from the Cenozoic of the Northwest Pacific, Leg 6. In Fischer, A. F., Heezen, B. C., et al., Initial Reports of the Deep Sea Drilling Project, v. 6: Washington (U.S. Government Printing Office), p. 1123-1127.

, 1973. Oxygen and carbon isotope analyses of Cretaceous and Tertiary foraminifera from the central north Pacific. In Winterer, E. L., Ewing, J. I., et al., Initial Reports of the Deep Sea Drilling Project, v. 17: Washington (U.S. Government Printing Office), p. 591-605.

Duplessy, J. C., 1972. La géochimie des isotopes stables du carbone dans la mer. Thesis, Paris University.

Kennett, J. P. and Shackleton, N. J., 1976. Oxygen isotopic evidence for the development of the psychrosphere $38 \mathrm{~m}$.y. ago, Nature, v. 260, p. 513-515.
Lancelot, Y., Hathaway, J. C., and Hollister, C. D., 1972. Lithology of sediments from the western North Atlantic Leg 11. In Hollister, C. D., Ewing, J. I., et al., Initial Reports of the Deep Sea Drilling Project, v. 11: Washington(U.S. Government Printing Office), p. 901-946.

Létolle, R., Bourbon, M., and Renard, M., 1978. Oxygen 18 and carbon 13 in carbonates of Leg 44 , with a comparison with alpine series. In Benson, W. E., Sheridan, R. E., et al., Initial Reports of the Deep Sea Drilling Project, v. 44: Washington (U.S. Government Printing Office), p. 567-574.

Margolis, S. V., Kroopnick, P. M., Goodney, D. E., Dudley, W. C., and Mahoney, M. E., 1975. Oxygen and carbon isotopes from calcareous nannofossils as paleo-oceanographic indicators, Science, v. 189, p. 555-557.

Savin, S. M., Douglas, R. G., and Stehli, F. G., 1975. Tertiary marine paleotemperatures, Geol. Soc. Am. Bull., v. 86, p. 1499-1510.

Shackleton, N. J., 1967. Oxygen isotope analyses and paleotemperatures reassessed, Nature, v. 215, p. 15-17.

Shackleton, N. J., and Kennett, J. P., 1975a. Paleotemperature history of the Cenozoic and the initiation of Antarctic glaciation: oxygen and carbon isotopes analyses in DSDP Sites 277, 279, and 281. In Kennett, J. P., Houtz, R. E., et al., Initial Reports of the Deep Sea Drilling Project, v. 29: Washington (U.S. Government Printing Office), p. 743-755.

, 1975b. Late Cenozoic oxygen and carbon isotopic changes at DSDP Site 284: implications for glacial history of the Northern Hemisphere and Antarctica. In Kennett, J. P., Houtz, R. E., et al., Initial Reports of the Deep Sea Drilling Project, v. 29: Washington (U.S. Government Printing Office), p. 801-807.

Schlanger, S. O., Douglas, R. G., Lancelot, Y., Moore, T. C., and Roth, P. H., 1973. Fossil preservation and diagenesis of pelagic-carbonates from the Magellan Rise, central north Pacific Ocean. In Winterer, E. L., Ewing, J. I., et al., Initial Reports of the Deep Sea Drilling Project, v. 17: Washington (U.S. Government Printing Office), p. 407-427. 